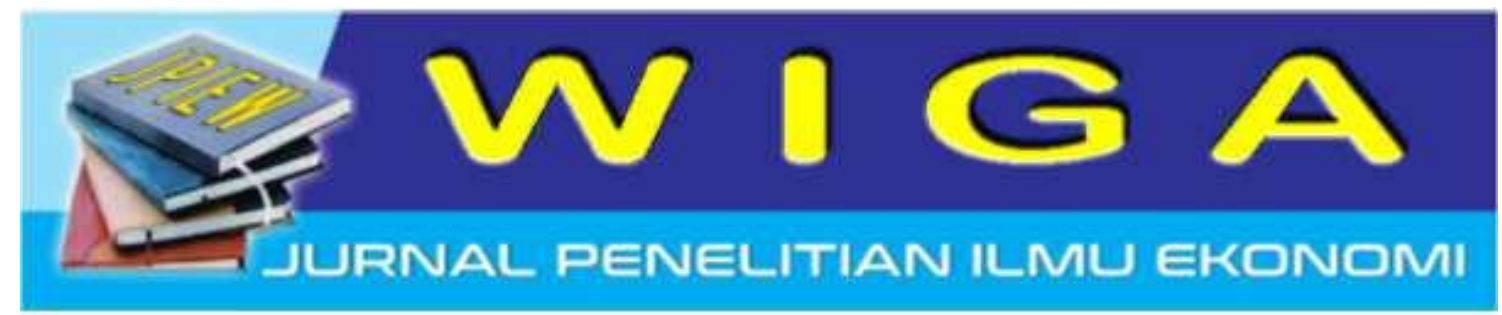

\title{
Analisis Motivasi dan Kinerja Karyawan Klinik Swasta di Kabupaten Lumajang Berdasarkan Kompensasi Yang Diberikan
}

\author{
Emmy Ermawati ${ }^{1}$ \\ STIE Widya Gama Lumajang \\ email : emmy.ermawati01@gmail.com \\ Noer Aisyah Barlian ${ }^{2}$ \\ STIE Widya Gama Lumajang \\ email: barlian.0301@gmail.com
}

\begin{abstract}
Abstrak
Penelitian ini bertujuan untuk mengidentifikasi pengaruh kompensasi langsung, kompensasi tidak langsung dan kompensasi non finansial terhadap motivasi serta kinerja karyawan klinik kesehatan swasta. Populasi dari penelitian ini adalah karyawan klinik swasta di Kabupaten Lumajangan dengan 34 responden yang digunakan sebagai sampel. Teknik analisis data menggunakan analisis regresi linier berganda. Hasil dari penelitian ini menunjukkan bahwa secara parsial semua variabel tidak berpengaruh signifikan terhadap motivasi dan kinerja. Sedangkan secara simultan ketiga variabel hanya berpengaruh signifikan terhadap motivasi tetapi tidak terhadap kinerja karyawan. Selain itu penelitian ini menunjukkan bahwa motivasi berpengaruh signifikan terhadap kinerja karyawan. Koefisien determinasi untuk variabel motivasi sebesar 58,9\% yang artinya variabel ini dapat dijelaskan oleh ketiga variabel bebas dalam penelitian ini. Hal ini berbeda dengan variabel kinerja yang hanya sebesar 14,2\%. Sedangkan untuk pengaruh motivasi terhadap kinerja memliki koefisien determinasi sebesar 14,2\%. Selanjutnya penelitian ini diharapkan dapat memberikan kontribusi dalam pengembangan kajian ilmu manajemen khususnya manajemen sumber daya manusia sehingga dapat menjadi acuan penelitian selanjunya.
\end{abstract}

Kata kunci: Kompensasi, Motivasi, Kinerja

\begin{abstract}
This study aims to identify the effects of direct compensation, indirect compensation and nonfinancial compensation on the motivation and performance of employees of private health clinics. The population of this research is private clinic employee in Lumajanga Regency with 34 respondents used as sample. Data analysis technique used multiple linear regression analysis. The results of this study indicate that partially all variables have no significant effect on motivation and performance. While simultaneously the three variables only have a significant effect on motivation but not on employee performance. In addition, this study
\end{abstract}

WIGA : Jurnal Penelitian IImu Ekonomi, Volume 8 Nomor $2 \mid 30$ 
indicates that motivation has a significant effect on employee performance. Coefficient of determination for motivation variable equal to 58,9\% which means this variable can be explained by three independent variable in this research. This is different from the performance variable which is only $14.2 \%$. As for the influence of motivation on the performance of coefficient of determination of 14.2\%. Furthermore, this research is expected to contribute in the development of management science studies, especially human resource management so that it can become a reference for further research

\section{Keyword : Compensation, Motivation, Performance}

\section{PENDAHULUAN}

Sistem kesehatan di Indonesia telah mengalami perkembangan yang pesat diberbagai bidangnya. Salah satunya adalah sistem cara bayar pasien kepada penyedia pelayanan kesehatan pemerintah maupun swasta. Hal ini mengharuskan pemimpin instansi kesehatan untuk mengembangkan instansinya sesuai dengan perkembangan yang semakin pesat ini. Perkembangan ini harus didasari dengan niat untuk memberikan pelayanan berkualitas kepada masyarakat sesuai dengan kebutuhannya.

Disisi lain pemerintah dalam UndangUndang Nomor 19 Tahun 2016 tentang Perubahan Kedua Atas Peraturan Presiden Nomor 12 Tahun 2014 tentang Jaminan Kesehatan menyatakan bahwa untuk penduduk Indonesia akan diwajibkan memiliki asuransi kesehatan. Kewajiban ini tentunya akan berpengaruh besar pada instansi kesehatan di Indonesia termasuk juga Lumajang. Oleh karena itu, pihak penyedia jasa kesehatan harus mampu memberikan pelayanan yang bermutu sehingga kebutuhan masyarakat akan pelayanan kesehatan dapat terpenuhi dengan maksimal. Salah satu faktor yang berpengaruh terhadap pemenuhan pelayanan kesehatan yang maksimal adalah petugas medis dalam instasi kesehatan tersebut. Dalam hal ini, petugas medis harus mendapatkan hak, berupa kopensasi, yang sesuai sehingga dapat menjalankan kewajibannya dengan baik. Pemberian kompensasi pada petugas medis sebenarnya sudah diatur oleh pemerintah Indonesia pada Peraturan Menteri Kesehatan No. 19 Tahun 2014 tentang
Penggunaan Dana Kapitasi Jaminan Kesehatan Nasional untuk Jasa Pelayanan Kesehatan dan Dukungan Biaya Operasional Pada fasilitas Kesehatan Tingkat Pertama Milik Pemerintah Daerah dinyatakan bahwa terdapat tambahan alokasi dana untuk instansi pemerintah dalam mengelola kesehatan masyarakat melalui Jaminan Kesehatan Nasional atau BPJS. Jaminan ini seharusnya membuat tenaga medis lebih semangat untuk meningkatkan kualitas dan kinerja instansi. Berbeda dengan instansi kesehatan dengan kepemilikan swasta dimana pengaturan keuangannya diatur sendiri sesuai dengan kebijakan pemilik, petugas medis menerima kompensasi sesuai dengan aturan atau kebijakan tersebut. Hal inilah yang menimbulkan beberapa kecenderungan antara petugas medis di instansi swasta jika kopensasi yang didapat tidak sama dengan yang didapat oleh petugas medis pada instansi pemerintah. Oleh karena itu penelitian ini diharapkan dapat menyelesaikan permasalahan ini sehingga selain dapat memenuhi kebutuhan masyarakat, instansi kesehatan swasta juga dapat memberikan kompensasi yang layak bagi tenaga medisnya.

Rivai dan Ella (2009) menyatakan bahwa kompensasi merupakan sesuatu yang diterima karyawan sebagai pengganti kontribusi jasa mereka pada perusahaan. Pemberian kompensasi merupakan salah satu pelaksanaan fungsi MSDM yang berhubungan dengan semua jenis pemberian penghargaan individual sebagai pertukaran dalam melaksanakan tugas keorganisasian. Sehingga dapat dikatakan bahwa kompensasi merupakan salah satu 
cara yang dianggap dapat meningkatkan motivasi dan kinerja petugas medis yang diharapkan dapat bermanfaat untuk pemenuhan kebutuhan kesehatan masyarakat. Menurut Koontz et al (1984), motivasi merupakan suatu reaksi yang diawali dengan adanya kebutuhan yang menimbulkan keinginan atas upaya mencapai tujuan, selanjutnya menimbulkan ketegangan dan kemudian menyebabkan timbulnya tindakan yang mengarah pada tujuan dan akhirnya dapat memuaskan. Berbeda dengan Koontz et al, Porter dan Lawler (1968) menjelaskan bahwa motivasi merupakan suatu proses dengan mana perilaku dibangkitkan, diarahkan dan dipertahankan selama berjalannya waktu. Selanjutnya Mangkunegara (2009) menyatakan bahwa kinerja sumber daya manusia merupakan istilah yang berasal dari kata Job Performance atau Actual Performance dimana kinerja karyawan merupakan suatu fungsi dari motivasi dan kemampuan untuk menyelesaikan tugas pekerjaan seseorang yang sepatutnya memiliki derajat kesediaan dan tingkat kemampuan tertentu.

Terdapat beberapa penelitian terdahulu yang digunakan sebagai acuhan dalam penelitian ini. Pertama terdapat penelitian Ni Made Nurchayani dan I.G.A. Dewi Adnyani (2016) mendapatkan beberapa kesimpulan antara lain kompensasi berpengaruh positif terhadap kepuasan kerja, motivasi berpengaruh positif dan signifikan terhadap kepuasan kerja, kompensasi berpengaruh positif dan signifikan terhadap kinerja karyawan, motivasi berpengaruh positif dan signifikan terhadap kinerja karyawan, kepuasan kerja berpengaruh positif dan signifikan terhadap kinerja karyawan serta kepuasan karyawan memediasi pengaruh kopensasi dan motivasi terhadap kinerja karyawan. Kesimpulan dihasilkan pada studi kasus di PT. Sinar Sosro Pabrik Bali dimana sebaiknya pemberian kompensasi dilakukan secara adil dan kegiatan motivasi dilakukan dengan promosi jabatan sesuai dengan kualifikasi yang ditetapkan sebelumnya. Selanjutnya Dinna Caesar (2014) menyatakan bahwa terdapat hubungan signifikan antara motivasi dan kinerja karyawan. Tanpa ada motivasi karyawan sulit untuk bekerja dengan baik sehingga kinerja yang baik tidak akan tercapai. Hal ini senada dengan yang disampaikan Ririvega Kasenda (2013) dimana hubungan kompensasi dan motivasi dengan kinerja karyawan sangat kuat. Berdasarkan uraian di atas maka penelitan ini dilakukan untuk mencari pengaruh pemberian kompensasi pada motivasi dan kinerja tenaga medis di instansi kesehatan atau klinik swasta di Kabupaten Lumajang. Oleh karena itu judul dari penelitian ini adalah "Pengaruh Kompensasi Finansial Langsung, Kompensasi Finansial Tidak Langsung dan Kompensasi Non Finansial Terhadap Motivasi dan Kinerja Karyawan di Klinik Swasta Kabupaten Lumjang". Penelitian ini diharapkan dapat memberikan masukan yang bermanfaat bagi pengelolah klinik kesehatan, petugas medis maupun masyarakat umum

\section{KAJIAN PUSTAKA Kompensasi}

Kompensasi merupakan sesuatu yang diterima karyawan sebagai pengganti kontribusi jasa mereka pada perusahaan. Pemberian kompensasi merupakan salah satu pelaksanaan fungsi MSDM yang berhubungan dengan semua jenis pemberian penghargaan individual sebagai pertukaran dalam melaksanakan tugas keorganisasian (Rivai dan Ella, 2009). Terdapat beberapa jenis kompensasi, antara lain;

a. Kompensasi Finansial Langsung

Berikut kompensasi yang tergolong pada finansial langsung;

1. Pembayaran gaji pokok dan upah

2. Pembayaran prestasi

3. Pembayaran insentif, komisi, bonus, bagian keuntungan dan opsi saham

4. Pembayaran tertangguh, tabungan hari tua dan saham kumulatif

b. Kompensasi Finansial Tidak Langsung 
Berikut kompensasi yang tergolong finansial tidak langsung;

1. Proteksi seperti asuransi, pesangon, pensiunan

2. Komisi luar jam kerja seperti lembur, hari besar, cuti, sakit, cuit hamil

3. Fasilitas seperti rumah, biaya pindah atau kendaraan

c. Kompensasi Non Finansial

Berikut beberapa kompensasi yang tergolong non finansial;

1. Kompensasi yang dikarenakan karir dapat berupa peluang promosi, pengakuan karya atau prestasi istimewa

2. Kompensasi non finansial yang diberikan pada lingkungan kerja dapat berupa pujian, kenyamanan dalam bekerja, lingkungan bekerja yang kondusif dan menyenangkan

\section{Motivasi}

Motivasi merupakan akibat suatu hasil yang ingin dicapai oleh seseorang dan perkiraan yang bersangkutan bahwa tindakannya akan mengarah kepada hasil yang diinginkannya. Artinya, apabila seseorang sangat menginginkan sesuatu dan jalan tampaknya terbuka untuk memperolehnya maka yang bersangkutan akan berupaya untuk mendapatkanya (Titisari, 2014). Hal ini sangatlah erat hubungannya dengan teori harapan pada buku "Work and Motivation" yang dikarang oleh Vroom (1995). Dengan cara yang sangat sederhana, teori harapan berkata bahwa jika seseorang menginginkan sesuatu dan harapan untuk memperolehnya cukup besar, maka yang bersangkutan akan sangat terdorong untuk memperoleh hasil yang diinginkan. Sebaliknya, jika harapan memperoleh hal tersebut kecil maka motivasi menjadi rendah. Hal ini juga berlaku untuk karyawan, sebagaimana yang dikatakan Boe (2002) dimana harapan-harapan ini berkaitan dengan kepercayaan karyawan yang tinggi terhadap organisasi atau perusahaanya. Dengan kata lain, ketika karyawan memiliki kepercayaan yang tinggi terhadap organisasinya maka mereka akan peduli terhadap masa depan dan keberhasilan organisasi tersebut sehingga mereka akan memahami peran mereka dan berusaha terbaik untuk kemajuan organisasi tersebut.

Dalam konteks ilmu psikologi, Abin Syamsuddin Makmun mengemukakan bahwa untuk memahami motivasi individu dapat dilihat dari beberapa indikator seperti dibawah ini;

a. Durasi kegiatan

b. Frekuensi kegiatan

c. Persisten pada kegiatan

d. Ketabahan, keuletan dan kemampuan dalam menghadapi rintangan dan kesulitan

e. Pengorbanan untuk mencapai tujuan

f. Tingkat aspirasi kehendak dicapai dengan kegiatan yang dilakukan

g. Tingkat kualifikasi prestasi atau produk (output) yang dicapai dari kegiatan yang dilakukan

h. Arah sikap terhadap sasaran kegiatan Sedangkan faktor yang mempengaruhi motivasi antara lain;

a. Intensif materi

Perihal yang dimaksud disini dapat berupa gaji yang diperoleh karyawan pada periode waktu tertentu sesuai dengan kebijakan instansi. Gaji menjadi penting dalam beberapa hal gaji menjamin suatu mata pencaharian sehingga mendorong untuk seseorang untuk bekerja. Besar gaji menunjukkan status pekerjanya dan kenaikan gaji merupakan penegasan keberhasilan. Dengan kata lain gaji yang tinggi dapat digunakan untuk jaminan kehidupan tanpa ada perasaan dan keterlibatan emosi yang lebih dalam dengan orang lain.

b. Intensif non materi

Hal yang bersifat non materi dapat berupa tanggungjawab, pengayaan pekerjaan, promosi yang sangat berpengaruh pada motivasi kerja menurut Suprianto dan Masyuri (2010)

\section{Kinerja Karyawan}


Mangkunegara (2009) menyatakan bahwa kinerja sumber daya manusia merupakan istilah yang berasal dari kata "Job Performance atau Actual Performance" yang berarti prestasi kerja atau prestasi yang sesungguhnya yang dicapai seseorang. Kinerja karyawan merupakan suatu fungsi dari motivasi dan kemampuan untuk menyelesaikan tugas pekerjaan seseorang yang sepatutnya memiliki derajat kesediaan dan tingkat kemampuan tertentu. Oleh karena itu tujuan dari penelitian terkait kinerja adalah sebagai bagian dari evaluasi dan pembangan dimana evaluasi berarti usaha untuk membandingkan kinerja karyawan satu dengan lainnya terhadap standar kerja yang telah ditentukan. Sedangkan pengembangan yang dimaksud adalah usaha untuk memberikan semangat dan memotivasi serta mengarahkan untuk mencapai peningkatan kinerja dalam upaya peningkatan karir (Supriyanto dan Machfudz, 2010).

Sebelum melakukan penelitian terkait dengan kinerja, maka diperlukan pengetahuan tentang unsur dari kinerja itu sendiri. Berikut unsur dari kenerja menurut Supriyanto dan Machfudz (2010).

a. Hasil fungsi pekerjaan

b. Faktor yang berpengaruh terhadap prestasi kerja karyawan seperto motivasi, kecakapan, persepsi peranan dan tugas serta hal lainnya.

c. Pencapaian tujuan organisasi

d. Periode waktu tertentu

Selain itu, Matis dan Jackson menyatakan bahwa penilaian kinerja karyawan juga dapat didasarkan atas kemampuan mereka dalam menyelesaikan pekerjaan dengan indikator sebagai berikut.

a. Kuantitas hasil kerja

b. Kualitas hasil kerja

c. Ketepatan waktu karyawan dalam menyelesaikan pekerjaannya.

\section{METODE PENELITIAN}

Penelitian ini menurut tingkat ekspanasinya merupakan penilitian yang bermaksud menjelaskan kedudukan variabel yang diteliti serta hubungan antara satu variabel dengan variabel yang lainnya. Oleh karena itu jenis penelitian ini adalah asosiasi dimana penelitian dilkakukan untuk mengetahui hubungan antara dua atau lebih variabel (Siregear, 2013). Penelitian ini menentukan pengaruh antara variabel kompensasi terhadap motivasi dan kinerja karyawan dimana variabel kompensasi terdiri dari kompensasi finansial langsung, tidak langsung dan non finansial.

Penelitian ini dilakukan terhadap karyawan paramedis di klinik swasta Kabupaten Lumajang. Hal ini dilakukan dengan pertimbangan dimana klinik swasta di kabupaten ini belum memiliki sistem pemberian kompensasi yang seragam dan belum melaksanakan akreditasi instansi sehingga sebagai masukan dalam memperbaiki sistem pemberian kompensasi kepada petugas medis. dalam hal ini karyawan paramedis ini merupakn objek dari penelitian ini. Karyawan paramedis diberikan kuesioner untuk menjaring persepsi mereka atas kinerja karyawan dan motivasi berdasarkan pemberian kompensasi di tempat mereka masing-masing. Setelah dilakukan penyebaran kuesioner didapat 34 responden yang digunakan sebagai sampel dalam penelitian ini.

\section{Teknik Analisis Data}

Pada tahap awal dilakukan pengujian instrumen penelitian karena berupa kuesioner, yaitu pengujian validitas dan reliabilitas. Selanjutnya dilakukan analisis regresi linier berganda dengan uji asumsi klasik yang meliputi pengujian normalitas data, multikolinearitas dan heteroskedastisitas. Tahap selanjutnya dilakukan pengujian hipotesis secara parsial dan simultan untuk setiap variabel yang digunakan dalam penelitian ini.

\section{HASIL DAN PEMBAHASAN Hasil Penelitian}

Pengujian instrumen penelitian memberikan hasil bahwa kuesioner valid dan reliabel menjaring pendapat responden dalam penelitian sedangkan untuk pengujian asumsi klasik didapat hasil bahwa data berdistribusi normal, bebas 
multikolineritas dan bebas heteroskedatisitas. Berikut merupakan persamaan regresi linier berganda yang didapat dari analisis dalam penelitian ini.

$$
\begin{aligned}
& Y_{1}= 17,115+0,256 \mathrm{X}_{1} \\
&+0,083 \mathrm{X}_{2} \\
&+0,567 \mathrm{X}_{3} \\
& Y_{2}= 28,774+0,222 X_{1} \\
&-0,237 X_{2} \\
&+0,024 X_{3} \\
& Y_{2}=24,873+0,175 Y_{1}
\end{aligned}
$$

\begin{tabular}{|c|c|c|c|}
\hline$Y_{1}$ & Variabel & btivasi & \\
\hline$Y_{2}$ & Variabel & nerja & \\
\hline$X_{1}$ & Variabel & mpensasi lang & \\
\hline$X_{2}$ & $\begin{array}{l}\text { Variabel } \\
\text { langsung }\end{array}$ & kompensasi & $\mathrm{d}$ \\
\hline$X_{3}$ & $\begin{array}{l}\text { Variabel } \\
\text { finansial }\end{array}$ & kompensasi & \\
\hline
\end{tabular}

Dimana;

Pengujian asumsi klasik dalam penelitian ini dilakukan berdasarkan setiap persamaan regresi linier berganda. Persamaan (1) didapat kesimpulan bahwa residu model berdistribusi normal, hasil ini berbeda dengan persamaan (2) dan (3) dimana hasil uji Kolmogorov-Smirnov menyatakan bahwa residu model tidak berdistribusi normal. Selanjutnya untuk hasil uji multikolinieritas didapat hasil bahwa persamaan regresi pada penelitian ini bebas dari multikolinieritas. Hal ini berlaku sama untuk pengujian heteroskedatisitas dimana didapat bahwa model regresi bebas dari heteroskedatisitas.

Pengujian hipotesis dilakukan secara parsial dan simultan. Untuk pengujian parsial didapat hasil bahwa (1) variabel kompensasi langsung $\left(\mathrm{X}_{1}\right)$ tidak berpengaruh signifikan secara parsial terhadap variabel motivasi $\left(\mathrm{Y}_{1}\right), \quad(2)$ variabel kompensasi tidak langsung $\left(\mathrm{X}_{2}\right)$ tidak berpengaruh signifikan secara parsial terhadap variabel motivasi $\left(\mathrm{Y}_{1}\right), \quad(3)$ variabel kompensasi non finansial $\left(\mathrm{X}_{3}\right)$ tidak berpengaruh signifikan secara parsial terhadap variabel motivasi $\left(\mathrm{Y}_{1}\right)$, (4) variabel kompensasi langsung $\left(\mathrm{X}_{1}\right)$ tidak berpengaruh signifikan secara parsial terhadap variabel kinerja karyawan $\left(\mathrm{Y}_{2}\right)$,
(5) variabel kompensasi langsung $\left(\mathrm{X}_{2}\right)$ tidak berpengaruh signifikan secara parsial terhadap variabel kinerja karyawan $\left(\mathrm{Y}_{2}\right)$, (6) variabel kompensasi langsung $\left(\mathrm{X}_{3}\right)$ tidak berpengaruh signifikan secara parsial terhadap variabel kinerja karyawan $\left(\mathrm{Y}_{2}\right)$, dan (7) variabel motivasi ( $\left.\mathrm{Y}_{1}\right)$ berpengaruh signifikan terhadap kinerja $\left(\mathrm{Y}_{2}\right)$. Selanjutnya untuk pengujian simultan didapat hasil bahwa seluruh varibel bebas dalam penelitian ini berpengaruh signifikan secara simultan terhadap motivasi namun tidak pada kinerja.

\section{Pembahasan}

Hasil penelitian menyatakan bahwa tingkat persetujuan responden cenderung kurang untuk setiap pernyataan yang diberikan dalam kuesioner yang diberikan. Selain itu pengisian indentitas tidak diberikan dengan lengkap baik itu dalam hal nama, umur bahkan bagian pekerjaan meskipun peneliti telah menjamin kerahasian data tersebut. Hal ini dirasa wajar karena materi yang diberikan terkait dengan kompensasi atau upah yang mereka dapat setelah melakukan pekerjaan. Jika dilihat dari sisi usia, responden berada pada selang umur yang produktif dengan kata lain mereka dapat menjawab dan memahami setiap penyataan yang diberikan pada kuesioner penelitian. Hal ini selaras dengan tingkat pendidikan setiap responden dimana SMA merupakan tingakt pendidikan terendah dan D4 merupakan tingkat pendidikan paling tinggi. Oleh karena itu peneliti merasa kuesioner yang dibagikan sudah sesuai sasaran dan baik untuk dijadikan sampel penelitian ini.

Variabel pertama yang digunakan dalam kuesioner adalah variabel kompensasi finansial langsung $\left(\mathrm{X}_{1}\right)$. Beberapa pernyataan yang diberikan dalam kuesioner sesuai dengan variabel ini adalah (1) Gaji yang saya terima selalu diberikan tepat waktu, (2) Gaji yang saya terima sudah sesuai dengan upah minimum di Kabupaten Lumajang, (3) Gaji yang saya terima sesuai dengan tanggung jawan yang diberikan kepada saya, (4) Gaji yang 
diberikan kepada saya sesuai dengan pengalaman yang saya miliki, (5) Gaji yang diberikan kepada saya sesuai dengan masa kerja saya, (6) Saya menerima kenaikan gaji secara berkala setiap tahunnya sesuai dengan tingkat inflasi yang ada, (7) Saya selalu mendapatkan insentif setiap tahun dari klinik, dan (8) Insentif yang saya terima sesuai dengan keuntungan yang diterima klinik. Semua pernyataan ini dibuat sesuai dengan definisi kompensasi finansial langsung yang berkaitan dengan pemberian gaji, insentif dan sebagainya. Hasil yang didapat dari pencatatan kuesioner diketahui bahwa responden belum menerima kompensasi finansial langsung secara benar dan sesuai. Mayoritas responden menyatakan ketidaksetujuanya pada setiap pernyataan yang ada terkait dengan variabel ini.

Variabel kedua adalah kompensasi finansial tidak langsung $\left(\mathrm{X}_{2}\right)$. Berikut beberapa pernyataan yang digunakan dalam kuesioner ini antara lain (1) Saya mendapatkan hak cuti sesuai dengan peraturan yang berlaku, (2) Klinik memberikan dana pensiun kepada saya sesuai dengan masa kerja saya, (3) Saya mendapatkan fasilitas poli klinik yang dapat dikunjungi setiap hari, (4) Saya menerima jaminan asuransi apabila mendapatkan pemeriksaan kesehatan di luar klinik, (5) Saya menerima jaminan asuransi kesehatan penuh untuk seluruh anggota keluarga saya, (6) Saya mendapatkan fasilitas makanan dari catering yang sudah memenuhi empat sehat lima sempurna, (7) Saya mendapatkan seragam klinik dengan kredibilitas klinik, dan (8) Saya selalu mendapatkan hal THR tepat pada waktunya. Dari semua pernyataan yang ada pada kuesioner, responden menunjukkan ketidaksetujuannya dengan mayoritas menjawab "tidak setuju" pada setiap pernyataan. Hal ini menunjukkan bahwa responden belum menerima dengan benar dan sesuai terkait dengan kompensasi tidak langsung yang seharusnya diberikan oleh klinik sesuai dengan peraturan yang berlaku.
Selanjutnya adalah variabel kompensasi non finansial. Berikut pernyataan yang digunakan pada kuesioner dalam penelitian ini, antara lain; (1) Program rekreasi telah dilaksanakan secara periodik untuk karyawan dan keluarganya, (2) Kondisi kerja berupa fasilitas (kamar mandi, tempat istirahat, tempat ibadah, dll) dan lingkungan klinik sangat mendukung dan memadai, (3) Hubungan antar karywan selama ini berjalan dengan baik dan harmonis, (4) Hubungan antar atasan dengan bawahan selama ini berjalan dengan baik, (5) Klinik ini memberikan rasa aman untuk saya bekerja, dan (6) Bagi karyawan yang berprestasi terdapat program promosi jabatan yang lebih tinggi. Dari semua pernyataan ini terdapat sebagaian responden yang tidak setuju namun mayoritas responden menyetujuai pernyataan terkait variabel ini. Hal ini menunjukkan bahwa pemenuhan kebutuhan responden terkait kompensasi non finansial cukup baik atau dengan kata lain responden sudah menerima kompensasi tersebut.

Pembahasan variabel sebelumnya merupakan variabel bebas yang digunakan dalam penelitian ini. Selanjutnya akan dibahas mengenai variabel terikat berupa motivasi $\left(\mathrm{Y}_{1}\right)$ dan kinerja karyawan $\left(\mathrm{Y}_{2}\right)$ sesuai dengan hasil dalam penelitian ini. Variabel motivasi diwakili oleh beberapa pernyataan sebagai berikut; (1) Saya selalu masuk kerja dan jarang absen, (2) Saya merasa sistem reward dan punishment yang diberikan meningkatkan motivasi saya, (3) Saya diberikan kesempatan untuk mengembangkan potensi yang saya miliki, (4) Saya mendapatkan posisi dan jabatan sesuai dengan ketrampilan dan kemampuan yang saya miliki, (5) Saya diberikan kesempatan oleh perusahaan untuk mengembangkan karir, (6) Saya menerima nasihat atau masukan dari pimpinan, (7) Saya melaksanakan pekerjaan dengan penuh rasa tanggung jawab untuk mendapatkan imbalan yang wajar, (8) Saya merasa sistem penggajian yang diterapkan klinik sudah sesuai dengan kebutuhan saya, (9) Saya merasa sistem pemberian bonus yang diberikan sesuan 
dengan prestasi kerja karyawan, dan (10) Saya memiliki minat kerja yang sangat tinggi terhadap setiap pekerjaan yang diberikan perusahaan. Berbeda dengan semua variabel bebas yang mayoritas responden menyatakan ketidaksetujuanya, variabel motivasi mendapatkan persetujuan dari responen. Hal ini menyatakan bahwa responen bekerja secara barik, selalu masuk kerja dan bekerja sesuai dengan aturan yang berlaku. Selanjutnya adalah variabel kinerja $\left(\mathrm{Y}_{2}\right)$, berikut pernyataan yang digunakan dalam kuesioner penelitian ini; (1) Saya dapat mengerjakan tugas dengan efektif, (2) Saya dapat melaksanakan pekerjaan secara hati-hati, (3) Bila perusahaan menghadapai masalah, saya tidak berdiam diri tetapu memberikan masukan yang bermanfaat, (4) Saya dalam melakukan pekerjaan dapat memanfaatkan waktu sebaik mungkin, (5) Saya memiliki keterampilan yang memadai mengenai pekerjaan yang saya lakukan, (6) Saya memiliki semangat dalam mengerjakan tugas-tugas yang diberikan perusahaan, (7) Saya dapat bekerja sama secara harmonis dalam tim, dan (8) Saya selalu berusaha untuk ramah dengan semua rekan kerja. Hasil pencatatan kuesioner untuk variabel kinerja karyawan menyatakan bahwa tingkat persetujuan responden cukup tinggi untuk setiap pernyataan yang digunakan. Hal ini menyatakan bahwa kinerja karyawan cukup bagus dalam hal pemenuhan pekerjaan, kerja sama dengan rekan lain serta penyelesaian masalah dalam pekerjaan.

Berdasarkan hasil pencatatan kuesioner diketahui bahwa responden memiliki tingkat persetujuan yang kurang untuk variabel bebas dan tingkat persetujuan yang cukup tinggi untuk variabel terikat. Hal ini menunjukkan untuk klinik swasta di Kabupaten Lumajang belum memberikan fasilitas berupa kompensasi yang sesuai kepada responden meskipun tingkat pendidikan yang dimiliki sudah cukup sesuai. Sedangkan untuk variabel motivasi dan kinerja karyawan tercatat bahwa responden melaksanakan pekerjaan dengan baik sesuai dengan latar belakang pendidikan responden. Hal ini merupakan sesuatu yang bagus mengingat bidang kesehatan merupakan salah satu bidang yang sangat dibutuhkan oleh masyarakat. Secara umum keberadaan klinik swasta memberikan kemudahan kepada masyarakat Lumajang untuk menjangkau pelayanan kesehatan lebih mudah, karena lokasi rumah sakit yang cenderung berada di pusat kota. Oleh karena itu pelayanan kesehatan yang baik akan sangat membantu masyarakat terutama yang berada di pedalaman Kabupaten Lumajang. Selanjutnya akan diberikan pembahasan untuk setiap hipotesis yang digunakan dalam penelitian ini.

\section{a. Pembahasan Hasil Pengujian Hipotesis Pertama}

Pembahasan ini berkaitan dengan hasil pengujian terhadap hipotesis pertama yang menyatakan bahwa kompensasi finansial langsung berpengaruh signifikan terhadap motivasi di klinik swasta Kabupaten Lumajang. Pembuktian hipotesis ini dilakukan dengan analisis data menggunakan regresi linier berganda. Hasil analisis menunjukkan bahwa pemberian kompensasi finansial langsung tidak berpengaruh signifikan terhadap motivasi karyawan secara parsial pada klinik kesehatan swasta di Kabupaten Lumajang ini. Hal ini ditunjukkan oleh hasil uji t dimana nilai Sig. sebesar 0,198 > $\alpha(0,05)$.

\section{b. Pembahasan Hasil Pengujian Hipotesis Kedua}

Pembahasan ini berkaitan dengan hasil pengujian terhadap hipotesis kedua yang menyatakan bahwa kompensasi tidak langsung berpengaruh signifikan terhadap motivasi di klinik swasta di Kabupaten Lumajang. Pembuktian hipotesis ini dilakukan dengan analisis data menggunakan regresi linier berganda. Hasil analisis menunjukkan bahwa pemberian kompensasi finansial tidak langsung tidak berpengaruh signifikan terhadap motivasi karyawan secara parsial pada klinik kesehatan swasta di Kabupaten Lumajang ini. Hal ini ditunjukkan oleh 
hasil uji t dimana nilai Sig. sebesar 0,878 > $\alpha(0,05)$.

\section{c. Pembahasan Hasil Pengujian Hipotesis Ketiga}

Pembahasan ini berkaitan dengan hasil pengujian terhadap hipotesis ketiga yang menyatakan bahwa kompensasi non finansial berpengaruh signifikan terhadap motivasi di klinik swasta di Kabupaten Lumajang. Pembuktian hipotesis ini dilakukan dengan analisis data menggunakan regresi linier berganda. Hasil analisis menunjukkan bahwa pemberian kompensasi non finansial tidak berpengaruh signifikan terhadap motivasi karyawan secara parsial pada klinik kesehatan swasta di Kabupaten Lumajang ini. Hal ini ditunjukkan oleh hasil uji t dimana nilai Sig. sebesar $0,131>\alpha(0,05)$.

\section{d. Pembahasan Hasil Pengujian}

\section{Hipotesis Keempat}

Pembahasan ini berkaitan dengan hasil pengujian terhadap hipotesis keempat yang menyatakan bahwa kompensasi finansial langsung berpengaruh signifikan terhadap kinerja karyawan di klinik swasta di Kabupaten Lumajang. Pembuktian hipotesis ini dilakukan dengan analisis data menggunakan regresi linier berganda. Hasil analisis menunjukkan bahwa pemberian kompensasi finansial langsung tidak berpengaruh signifikan terhadap kinerja karyawan secara parsial pada klinik kesehatan swasta di Kabupaten Lumajang ini. Hal ini ditunjukkan oleh hasil uji $\mathrm{t}$ dimana nilai Sig. sebesar 0,098 > $\alpha(0,05)$.

\section{e. Pembahasan Hasil Pengujian Hipotesis Kelima}

Pembahasan ini berkaitan dengan hasil pengujian terhadap hipotesis kelima yang menyatakan bahwa kompensasi finansial tidak langsung berpengaruh signifikan terhadap kinerja karyawan di klinik swasta di Kabupaten Lumajang. Pembuktian hipotesis ini dilakukan dengan analisis data menggunakan regresi linier berganda. Hasil analisis menunjukkan bahwa pemberian kompensasi finansial tidak langsung tidak berpengaruh signifikan terhadap kinerja karyawan secara parsial pada klinik kesehatan swasta di Kabupaten Lumajang ini. Hal ini ditunjukkan oleh hasil uji t dimana nilai Sig. sebesar 0,516 > $\alpha(0,05)$.

\section{f. Pembahasan Hasil Pengujian Hipotesis Keenam}

Pembahasan ini berkaitan dengan hasil pengujian terhadap hipotesis keenam yang menyatakan bahwa kompensasi non finansial berpengaruh signifikan terhadap kinerja karyawan di klinik swasta di Kabupaten Lumajang. Pembuktian hipotesis ini dilakukan dengan analisis data menggunakan regresi linier berganda. Hasil analisis menunjukkan bahwa pemberian kompensasi non finansial tidak berpengaruh signifikan terhadap kinerja karyawan secara parsial pada klinik kesehatan swasta di Kabupaten Lumajang ini. Hal ini ditunjukkan oleh hasil uji t dimana nilai Sig. sebesar $0,923>\alpha(0,05)$.

\section{g. Pembahasan Hasil Pengujian Hipotesis Ketujuh}

Pembahasan ini berkaitan dengan hasil pengujian terhadap hipotesis ketujuh yang menyatakan bahwa kompensasi finansial langsung, kompensasi finansial tidak langsung dan kompensasi non finansial berpengaruh signifikan secara simultan terhadap motivasi di klinik swasta di Kabupaten Lumajang. Pembuktian hipotesis ini dilakukan dengan analisis data menggunakan regresi linier berganda. Hasil analisis menunjukkan bahwa pemberian kompensasi finansial langsung, tidak langsung dan non finansial berpengaruh signifikan terhadap motivasi karyawan secara simultan pada klinik kesehatan swasta di Kabupaten Lumajang ini. Hal ini ditunjukkan oleh hasil uji $\mathrm{F}$ dimana nilai Sig. sebesar $0,000<\alpha(0,05)$.

\section{h. Pembahasan Hasil Pengujian} Hipotesis Kedelapan

Pembahasan ini berkaitan dengan hasil pengujian terhadap hipotesis ketujuh yang menyatakan bahwa kompensasi finansial langsung, kompensasi finansial tidak langsung dan kompensasi non finansial berpengaruh signifikan secara simultan terhadap kinerja karyawan di klinik swasta di Kabupaten Lumajang. Pembuktian hipotesis ini dilakukan dengan analisis data menggunakan regresi linier berganda. Hasil analisis menunjukkan bahwa 
pemberian kompensasi finansial langsung, tidak langsung dan non finansial tidak berpengaruh signifikan terhadap kinerja karyawan secara simultan pada klinik kesehatan swasta di Kabupaten Lumajang ini. Hal ini ditunjukkan oleh hasil uji $F$ dimana nilai Sig. sebesar 0,197> $\alpha(0,05)$.

\section{i. Pembahasan Hasil Pengujian Hipotesis Kesembilan}

Pembahasan ini berkaitan dengan hasil pengujian terhadap hipotesis ketsembilan yang menyatakan bahwa motivasi berpengaruh signifikan terhadap kinerja karyawan di klinik swasta di Kabupaten Lumajang. Pembuktian hipotesis ini dilakukan dengan analisis data menggunakan regresi linier berganda. Hasil analisis menunjukkan bahwa motivasi berpengaruh pada kinerja karyawan pada klinik kesehatan swasta di Kabupaten Lumajang ini. Hal ini ditunjukkan oleh hasil uji t dimana nilai Sig. sebesar $0,028<\alpha(0,05)$.

\section{KESIMPULAN DAN SARAN Kesimpulan}

Berdasarkan hasil penelitian dan pembahasan yang telah diuraikan di atas, maka dapat diambil beberapa kesimpulan sebagai berikut :

a. Kompensasi finansial langsung tidak berpengaruh signifikan terhadap motivasi secara parsial di klinik swasta Kabupaten Lumajang.

b. Kompensasi finansial tidak langsung tidak berpengaruh signifikan terhadap motivasi secara parsial di klinik swasta Kabupaten Lumajang

c. Kompensasi non finansial tidak berpengaruh signifikan terhadap motivasi secara parsial di klinik swasta Kabupaten Lumajang

d. Kompensasi finansial langsung tidak berpengaruh signifikan terhadap kinerja karyawan secara parsial di klinik swasta Kabupaten Lumajang

e. Kompensasi finansial langsung tidak berpengaruh signifikan terhadap kinerja karyawan secara parsial di klinik swasta Kabupaten Lumajang f. Kompensasi finansial langsung tidak berpengaruh signifikan terhadap kinerja karyawan secara parsial di klinik swasta Kabupaten Lumajang

g. Kompensasi finansial langsung, tidak langsung dan non finansial berpengaruh signifikan terhadap motivasi secara simultan di klinik swasta Kabupaten Lumajang

h. Kompensasi finansial langsung, tidak langsung dan non finansial tidak berpengaruh signifikan terhadap kinerja karyawan secara simultan di klinik swasta Kabupaten Lumajang

i. Motivasi berpengaruh signifikan terhadap kinerja karyawan di klinik swasta Kabupaten Lumajang

\section{Saran}

Atas hasil penelitian dan pembahasan di atas, maka diberikan saran-saran kepada beberapa pihak sebagai berikut :

a. Bagi Pihak Klinik Swasta di Kabupaten Lumajang.

Pimpinan Klinik Swasta di Kabupaten Lumajang, agar tetap memperhatikan kebutuhan karyawan terkait dengan pemberian kompensasi serta memperhatikan kesejahterahan karyawan. Hal ini sepenuhnya untuk menghindari penurunan pelayanan kesehatan di Kabupaten Lumajang.

b. Bagi Karyawan Kesehatan Klinik Swasts di Kabupaten Lumajang

Setiap tugas yang dilakukan dalam bidang kesehatan memiliki tugas yang berkaitan dengan pelayanan kepada masyarakat. Oleh karena itu disarankan kepada setiap karyawan untuk selalu meningkatkan kemampuan diri dan selalu menjaga motivasi diri untuk memberikan pelayanan yang terbaik kepada masyarakat. Menyesuiakan dan membuat lingkungan kerja menjadi nyaman dna menyenangkan akan membuat hal ini menjadi salah satu sumber kepuasan kerja yang dapat meningkatkan kinerja.

c. Bagi Penelitian Selanjutnya 
Keterbatasan penelitian ini adalah hanya meneliti pada pemberian kompensasi karyawan, oleh karena itu bagi peneliti selanjutnya disarankan untuk melakukan penelitian yang meneliti variabel lain yang dapat mempengaruhi motivasi dan kinerja. Mengingat responden yang diteliti berbeda karakternya dengan sumber daya manusia maka akan sangat menarik jika sering dilakukan penelitian dengan obyek program pemberdayaan masyarakat.

\section{DAFTAR PUSTAKA}

Adelia, A.A Sg Rini Candra dan Ni Wayan Mujiati.2016. Pengaruh Kompensasi, Gaya

Kepemimpinan Dan Stres Kerja Terhadap Kepuasan Kerja Karyawan Di Rs Dharma Kerti. Bali; E-Jurnal Manajemen Unud, Vol. 4, No. 4, 2016: 3335-3363 ISSN : 2302-8912

Hartati, Sri dan Lina Handayani dan Solikhah. 2011. Hubungan Kepuasan Kerja Dengan Prestasi Kerja Perawat Di Instalasi Rawat Inap Rumah Sakit Islam Klaten. Klaten; Fakultas Kesehatan Masyarakat Universitas Ahmad Dahlan. ISSN : 1978-0575

Irawati, Rina dan Yuyuk Liana.2013. Pengaruh Gaya Kepemimpinan Transformasional Dan Kepuasan Kerja Terhadap Kinerja Karyawan Dengan Komitmen Organisasi Sebagai Variabel Antara. Malang; STIE Malangkuçeçwara Malang. ISSN No. 1978-6034

Khairiyah dan Nur Syaima Annisa. 2010. Pengaruh Kepuasan Kerja, Gaya Kepemimpinan, Dan Motivasi Kerja Terhadap Kinerja Karyawan Pada Pt Nutricia Indonesia Sejahtera. Bandung; Vol. 5 Oktober 2013 ISSN: $1858-2559$

Kuncoro, Mudrajad. 2007. Metode Kuantitatif. Unit Penerbit dan Percetakan.(UPP) STIM YKPN. Yogyakarta.

Liana, Yuyuk dan Rina Irawati. 2014. Peran Motivasi, Disiplin Kerja
Terhadap Komitmen Karyawan Dan Kinerja Karyawan Pada Perusahaan Air Minum Di Malang Raya.Malang: STIE Malangkucecwara Malang

Mangkunegara, Anwar Prabu. 2009. Manajemen Sumber Daya Mnausia. Perusahaan Bandunga:Remaja Rosdakarya

Mujiatun, Siti. 2011. Pengaruh Gaya Kepemimpinan Terhadap Kinerja Karyawan Di Yayasan Pendidikan Sinar Husni. Medan; jurnal manajemen \& bisnis vol 11 no. 01 april 2011 issn1693-7619.

Nugroho, Yohanes Anton. 2011. It's Easy Olah Data Dengan SPSS. Skripta Media Creative. Yogyakarta

Panjaitan, Hotman.2010. Pengaruh kepemimpinan terhadap kinerja paramedis dan dampaknya pada mutu pelayanan di rsud pasuruan. Pasuruan; Jurnal Riset Ekonomi \& BisnisVol. XX, No. X, IX 2010ISSN: 1979-7117

Pentania, Maria dan Rahman Kadir, Sudirman Natsir. 2013. Pengaruh Gaya Kepemimpinan Dan Kepuasan Kerja Terhadap Kinerja Karyawan Di Rsud Mimika Provinsi Papua Tahun 2013. Papua; JST Kesehatan Januari 2014, Vol.4 No.1 : 87 - 95 ISSN 2252-5416 30

Posuma , Christilia O. 2013. Kompetensi, Kompensasi, Dan Kepemimpinan Pengaruhnya Terhadap Kinerja Karyawan Pada Rumah Sakit Ratumbuysang Manado. Manado; Fakultas Ekonomi dan Bisnis, Jurusan Manajemen Universitas Sam Ratulangi Manado. ISSN 2303-1174

Prihananto, Aji Dwi. 2006. Penerapan Balanced Scorecard Pada Badan Usaaha Berbentuk Rumah Sakit (Studi Kasus Rumah Sakit Kristen Tayu Putih). Semarang.

Putri, Putu Yudha Asteria dan Made Yenni Latrini. 2013. Pengaruh Kepuasan Kerja Terhadap Kinerja Karyawan Sektor Publik, Dengan In-Role Performance Dan Innovative Performance Sebagai Variabel Mediasi. Bali; E-Jurnal Akuntansi 
Universitas Udayana 5.3 (2013):627638 ISSN: 2302-8556

Rivai, Veithzal dan Ella Jauvani Sagala. 2009. Manajemen Sumber Daya Manusia Untuk Perusahaan. Jakarta: Rajawali Pers

Sahrah, Alimatus. 2012. Organizational Citizenship Behavior Ditinjau Dari Kepuasan Kerja Dan Jenis Kelamin Para Perawat Rumah Sakit. Yogyakarta:Universitas Mercu Buana.http://fpsi.mercubuanayogya.ac.id/wpcontent/uploads/2012/ 06/alin_kepuasankerja.pdf

Santoso, Singgih. 2012. Panduan Lengkap SPSS Versi 20. Penerbit PT Elex Media Komputindo.Jakarta.

Siregar, Syofian. 2013. Metode Penelitian Kuantitatif: Dilengkapi dengan Perbandingan Perhitungan Manual \& SPSS. Jakarta: Kencana Prenada Media Group

Subanegara, Hanna. 2005. Diamond Head Drill Dan Kepemimpinan Dalam Manajemen Rumah Sakit. Yogyakarta; Penerbit ANDI Yogyakarta

Sugiyono. 2009. Metode Penelitian Bisnis. CV. Alfabeta. Bandung.

Supri, S.F. 2006. Kebijakan Arah Pengembangan Rs Di Indonesia. Yogyakarta; PELKESI

Supriyanto, Achmad Sani dan Masyhuri Machfudz. 2010. Metodologi Riset Manajemen Sumberdaya Manusia. Malang; UIN MALIKI PRESS

Titisari, Purnamie. 2014.Peran Organizatonal Citizenship Behavior (Ocb). Jember:Mitra Wacana Media

Timothy C, Obiwuru, Okwu, dkk. 2001. Effects Of Leadership Style On Organizational Performance: A Survey Of Selected Small Scale Enterprises In Ikosi-Ketu Council Development Area Of Lagos State, Nigeria. Australian Journal of Business and Management Research Vol.1 No.7 [100-111] 31

Trang, Dewi Sandy.2013.Gaya Kepemimpinan Dan Budaya Organisasi Pengaruhnya Terhadap
Kinerja Karyawan (Studi Di Perwakilan Bpkp Provinsi Sulawesi Utara). Sulawesi Utara: Jurnal EMBA Vol.1 No.3 September 2013, Hal. 208-216 